\title{
Quality and Conservation of Riparian Forest in a Mountain Subtropical Basin of Argentina
}

\author{
Romina Daiana Fernández, ${ }^{1}$ Sergio Javier Ceballos, ${ }^{1}$ Ana Lucía González Achem, \\ Margarita del Valle Hidalgo, ${ }^{3}$ and Hugo Rafael Fernández ${ }^{2}$ \\ ${ }^{1}$ Instituto de Ecología Regional, UNT-CONICET, CC 34, Yerba Buena, 4107 Tucumán, Argentina
${ }^{2}$ Instituto de Biodiversidad Neotropical, UNT-CONICET, CC 34, Yerba Buena, 4107 Tucumán, Argentina
${ }^{3}$ Facultad de Ciencias Naturales e IML, Miguel Lillo 205, 4000 Tucumán, Argentina \\ Correspondence should be addressed to Ana Lucía González Achem; anagonzalezachem@gmail.com
}

Received 31 December 2015; Revised 10 April 2016; Accepted 3 May 2016

Academic Editor: Ram Chander Sihag

Copyright (c) 2016 Romina Daiana Fernández et al. This is an open access article distributed under the Creative Commons Attribution License, which permits unrestricted use, distribution, and reproduction in any medium, provided the original work is properly cited.

\begin{abstract}
The aims of this work were to describe the conservation status of riparian forests located in a mountain subtropical basin of Tucumán province, Argentina, and assess how the quality of riparian forests is related with altitude, plant species richness, proportion of exotic species, and Total Suspended Solids (TSS) in adjacent rivers. Composition and species richness of riparian forests were studied at 16 sites located along an altitudinal gradient and TSS was determined from water samples collected in each site. In order to evaluate conservation status of riparian forests, we calculated an index of Quality of Yungas Riparian Forests (QBRy). We recorded 90 plant species at all sites, from which 77\% were native. QBRy index was mainly associated with altitude and varied from riparian forests with good preservation or slightly disturbed to those with extreme degradation. At lower altitude, forests were more disturbed, more invaded by exotic plant species, and closer to urban and cropped areas. QBRy was not correlated with species richness or TSS. Like other riparian forests of Argentina, plant species invasion increased their degradation; therefore, future studies should focus on native riparian forests conservation and on the management of invasive plant species, which affect their quality.
\end{abstract}

\section{Introduction}

Riparian ecosystems constitute a complex association of organisms and their environment, adjacent to a river [1]. They are also called buffer zones, since one of their main functions is to dampen the impact of human activities on the water body [2]. The riparian ecosystem supports a zone of vegetation that is structural and floristically different from adjacent habitats that they are integrated with [3]. Various human activities have led to the deterioration and/or change at the structure of riparian vegetation. The removal of riparian forests can change the energy dynamics of rivers, from heterotrophic systems (where production is based on the entry of leaves and other materials from land) to autotrophic systems where production is based on algae [4]. These changes directly affect the composition of aquatic biota that feed on organic matter entering from the outside [5].
An issue of special interest is the removal of vegetation cover from the riparian zone, which causes an increase in the load of Total Suspended Solids (TSS) in rivers; the latter directly affects the ecological discharge, which reduces their ability to support life [6]. Poff et al. [7] define ecological discharge as the quality, quantity, and flow regime needed to sustain aquatic ecosystems and the benefits and ecosystem services on which human society depends. Increasing TSS reduces light availability for producers of the aquatic system and consequently modifies the whole food chain [8]. Strand and Merritt [9] observed that land use change in areas surrounding water bodies resulted in decreased riparian vegetation and a consequent increase in nutrients in the water due to the drag of cultivated soil nutrients. The advancement of agricultural activities has thus resulted in the degradation of riparian vegetation and water quality [10]. 
In Argentina, changes in the use of land surrounding water bodies and pollution have had a deep impact on the functionality of riparian ecosystems [11-17]. These changes have led to the introduction of exotic plant species $[18,19]$ that may cause the extinction of local plant species [20]. In particular, the mountain rivers of northwestern Argentina, which include the streams of Salí River Basin, our study area, suffer severe environmental degradation, mainly due to their hydrological richness benefits to livestock and agricultural activities. The importance of riparian buffers in the integrity of the aquatic and terrestrial ecosystems is critical, and then determining their ecological and environmental quality is becoming increasingly important [21].

QBR index ("quality of the riparian forest"), proposed by Munné et al. [22], is currently the most widely used measure for the analysis of river banks; it allows describing the quality of vegetation in situ. QBR index is useful for assessing the quality of the riparian forest and the degree of alteration of the waterfront in four separate blocks; three of them are based on riparian vegetation characteristics (coverage, structure, and nature), while the fourth referred to changes in the river channel (for details see [22]). Several authors adapted QBR index according to the study area [23] for riparian forests of Spain; [24] for the Argentinean Patagonia; [25] for Chile; $[17,26]$ for riparian forests of the Argentinean Yungas. All of them highlight the increasing degradation of riparian areas. In this work, we use the QBRy index by Sirombra and Mesa [26] that amends three of the four items of the original index to take into account the characteristics and changes in the rivers of Yungas (for details see [27]).

The aims of this paper are (1) to describe the conservation status of the riverbanks of rivers and streams in a subtropical mountain basin of Tucumán province, Argentina; (2) to analyze how the quality of riparian vegetation and the species composition are related with altitude, species richness, and proportion of exotic species of the region; and (3) to evaluate the influence of the quality of riparian vegetation in the water content of Total Suspended Solids.

\section{Materials and Methods}

2.1. Study Area. Salí River Basin is the main hydrological basin of the province of Tucumán, Argentina. It is an endorheic system, covering about $45 \%$ of the province, and flows into the Mar Chiquita Lagoon in the province of Córdoba. The climate of the region is subtropical with marked seasonality. The average range of annual precipitation goes from 900 to $1500 \mathrm{~mm}$, concentrated in summer (80\%) [28], and the average annual temperature is $14^{\circ} \mathrm{C}$.

The study area (Figure 1) includes riparian forests belonging to the Yungas and Dry Chaco phytogeographic provinces [29]. Yungas is the southern-most extension of Neotropical Andean forests [30] and extends along discontinuous mountain ranges at NW Argentina. Yungas ecoregion is a forest which has an area of $700 \mathrm{~km}$ extent and $50 \mathrm{~km}$ width and has a strong altitudinal gradient that results in floristic stratification [31]. Therefore, Yungas presents three main altitudinal belts, identified as "selva pedemontana" (400-700 m a.s.l.), "selva montana" (700-1500 m a.s.l.), and "bosque montano"
(1500-2700 $\mathrm{m}$ a.s.l.) [32]. This work was conducted in riparian forests of "selva pedemontana" and "selva montana." The predominant canopy vegetation is dominated by Blepharocalyx salicifolius (Myrtaceae), Ocotea porphyria (Lauraceae), and Pisonia ambigua (Nyctaginaceae); and understory tree composition (5-12 $\mathrm{m}$ ) is dominated by Eugenia uniflora (Myrtaceae), Piper tucumanum (Piperaceae), and Allophylus edulis (Sapindaceae) [33]. The main economic activities that affect the Yungas are agriculture and livestock [17, 34]. Dry Chaco is one of the largest forest biomes of Argentina. This habitat is characterized by thicket and thorny vegetation and it is the most unexplored and least documented region in the country [35]. The predominant vegetation is deciduous dry forests, but there are also palms, savannas, and halophytic steppes [29]. In Chaco, there are three main subregions distinguished by climatic conditions: "Semiarid Chaco," "Chaco Serrano," and "Arid Chaco" [36]. This work was carried on riparian forests of "Chaco Serrano" and "Semiarid Chaco." Serrano Chaco is dominated by Schinopsis haenkeana and Lithraea molleoides [29, 36]. Semiarid Chaco is a xerophytic semideciduous forest, which before human intervention had a canopy dominated by Schinopsis quebracho-colorado and Aspidosperma quebracho-blanco [37]. For over a century, the region has been under sustained degradation and loss of natural heritage; the unplanned extractive use of natural resources is the main cause. In addition to the livestock and logging activities, in the last years, it was developed as an unplanned expansion of agriculture on a large scale [38].

2.2. Characterization of the Riverbank. We worked with a total of 16 sites whose encodings, coordinates, and main characteristics are shown in Table 1. In each sampling point, we established transects of 100 m length by 5 meters' width, on both banks of the watercourse. At each transect, we recorded plant species richness and we calculated QBRy index $[15,26]$. The quality riparian forest index (QBR) was designed to study the ecological quality of riparian forests from Spain [22]. The index consists of 4 sections and each of them is assigned a score between 0 and 25. The sum of the 4 sections represents thus the final score and ranks between 0 and 100. Within each section, elements which enhance the quality of riparian forests accumulate points, while those which lead to reductions in the quality of forests are given negative scores. Three of four sections of this index were modified by Sirombra [27] for riparian forests of Yungas rivers. The new index was called "QBRy" (Quality of Yungas Riparian Forests Index) and takes into account the percentage of native and exotic species of trees and shrubs for vegetation cover estimation. These 4 sections are vegetation cover, vegetation structure, vegetation quality, and degree of naturalness of the river channel. The obtained QBRy values allowed us to identify five ranges of quality of the banks: very good ( $>90)$; good, slightly disturbed (75-90); intermediate, start of alteration (50-70); bad, strong alteration (30-50); and bad, extreme degradation $(<25)$.

The vegetation sampling was conducted in 2012 and repeated in 2013 to improve estimates of QBRy index and to corroborate the species identification. We used the Catalogue of Vascular Plants of the Southern Cone [38] for identification 


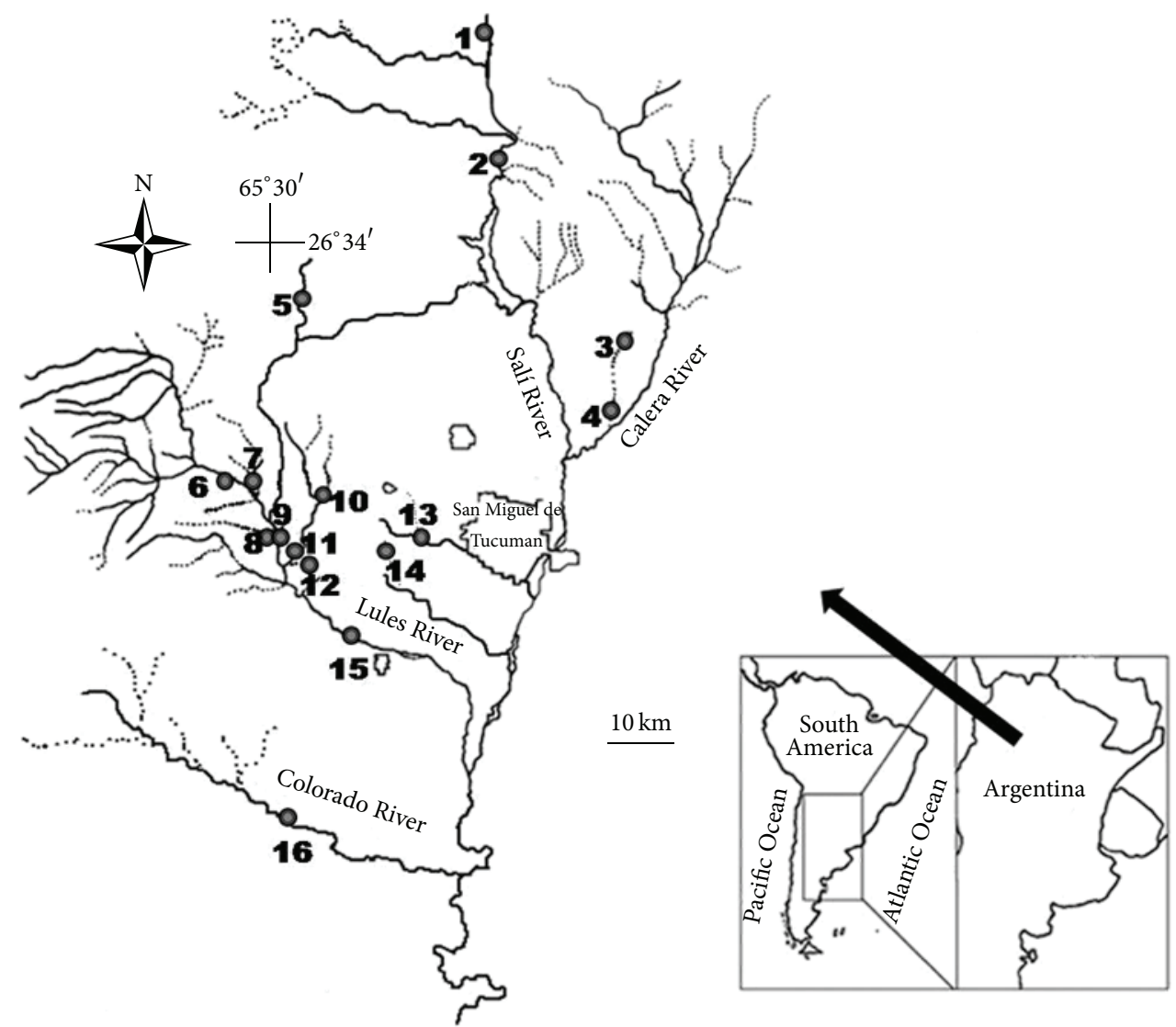
(1) Sa1
(9) Lu3
(2) $\mathrm{Sa} 2$
(10) SJ1
(3) LP1
(11) SJ2
(4) LP2
(12) LN1
(5) Ra1
(13) $\mathrm{Mu} 1$
(6) Gr1
(14) SP1
(7) $\mathrm{Lu} 1$
(15) Lu4
(8) Lu2
(16) $\mathrm{Co} 1$

FIgURE 1: Study area. Each numerated spot corresponds to a sampling site. Sites codes are on the left corner. Sites names are in Table 1.

of plant species and Tropicos [39] for updating scientific names.

We collected and preserved surface water samples for analysis of TSS in the laboratory, following IRAM protocols [40]. These data were taken during the years 2012 (October) and 2013 (March, May, and August), to represent dry and wet season. The water for TSS determination was analyzed following Volumetric Method: we put $80 \mathrm{~mL}$ of each water sample, previously agitated, into a porcelain capsule and heated it to $105^{\circ} \mathrm{C}$ for 24 hours. Then, we cooled the capsule in a vacuum container to prevent sample wet. To determine the weight of Total Suspended Solids (TSS) in the water sample, we weighed the empty capsules, then filled them with water sample, and subsequently made a comparison [41, 42]. For sites Ral, LN1, Mul, and SP1, we used data from Carrasco [43] corresponding to the years 2011 and 2012.

2.3. Data Analysis. All the sampled sites were ranked using the value of QBRy index, considered as an indicator of the conservation status of riparian forests. We evaluated whether riparian forests with less invasive species, higher species richness, and higher altitudes had a more suitable conservation status. For this purpose, we performed Pearson correlations between QBRy and plant species richness, percentage of exotic species, and altitude.

Changes in species composition were analyzed with a NMDS (Nonmetrical Multidimensional Scaling), based on a Bray Curtis similarity matrix of the sites $(n=16)$ calculated from the presence-absence of plant species. We also included a secondary matrix of altitude. Autopilot mode ("slow and thorough") was used to decide the appropriate number of dimensions [44]. The choice of two dimensions was based on a final stress (an index of the dissimilarities between the distances in the ordination plot and the distances in the matrix of Bray Curtis) equal to 20.4 and different from random (Monte Carlo test $=250$ runs, $p=0.04$ ) [44]. The NMDS considers that closer sites in the ordination plot have a similar plant species composition. 
TABLE 1: Main characteristics of the sampled sites.

\begin{tabular}{|c|c|c|c|c|c|c|c|}
\hline Name of the sites & Codification & $\begin{array}{c}\text { Geographical } \\
\text { coordinates }\end{array}$ & $\begin{array}{l}\text { Altitude } \\
\text { (m a.s.l.) }\end{array}$ & QBRy & $\begin{array}{c}\text { Taxa } \\
\text { richness }\end{array}$ & $\begin{array}{l}\text { \% native } \\
\text { species }\end{array}$ & $\begin{array}{c}\% \text { exotic } \\
\text { species }\end{array}$ \\
\hline Salí River 1 & Sal & $\begin{array}{l}26^{\circ} 13^{\prime} 56.27^{\prime \prime} \mathrm{S} \\
65^{\circ} 15^{\prime} 10.43^{\prime \prime} \mathrm{W}\end{array}$ & 765 & 55 & 26 & 90 & 10 \\
\hline Salí River 2 & $\mathrm{Sa} 2$ & $\begin{array}{l}26^{\circ} 28^{\prime} 33.29^{\prime \prime} \mathrm{S} \\
65^{\circ} 12^{\prime} 43.70^{\prime \prime} \mathrm{W}\end{array}$ & 650 & 35 & 14 & 100 & 0 \\
\hline La Perdiz Stream 1 & LP1 & $\begin{array}{c}26^{\circ} 42^{\prime} 44.00^{\prime \prime} \mathrm{S} \\
65^{\circ} 8^{\prime} 39.40^{\prime \prime} \mathrm{W}\end{array}$ & 529 & 5 & 15 & 21 & 79 \\
\hline La Perdiz Stream 2 & LP2 & $\begin{array}{l}26^{\circ} 43^{\prime} 8.00^{\prime \prime} \mathrm{S} \\
65^{\circ} 9^{\prime} 20.40^{\prime \prime} \mathrm{W}\end{array}$ & 496 & 25 & 9 & 45 & 55 \\
\hline Raco River 1 & Ral & $\begin{array}{c}26^{\circ} 40 / 40.00^{\prime \prime} \mathrm{S} \\
65^{\circ} 25^{\prime} 39.00 \mathrm{~W}\end{array}$ & 1168 & 60 & 23 & 91 & 9 \\
\hline Grande River 1 & Grl & $\begin{array}{l}26^{\circ} 46^{\prime} 21.98^{\prime \prime} \mathrm{S} \\
65^{\circ} 27^{\prime} 57.59^{\prime \prime} \mathrm{W}\end{array}$ & 918 & 30 & 5 & 75 & 25 \\
\hline Lules River 1 & Lu1 & $\begin{array}{l}26^{\circ} 46^{\prime} 23.16^{\prime \prime} \mathrm{S} \\
65^{\circ} 27^{\prime} 50.04^{\prime \prime} \mathrm{W}\end{array}$ & 909 & 30 & 8 & 75 & 25 \\
\hline Lules River 2 & Lu2 & $\begin{array}{l}26^{\circ} 47^{\prime} 28.20^{\prime \prime} \mathrm{S} \\
65^{\circ} 27^{\prime} 8.04^{\prime \prime} \mathrm{W}\end{array}$ & 848 & 80 & 10 & 100 & 0 \\
\hline Lules River 3 & Lu3 & $\begin{array}{l}26^{\circ} 47^{\prime} 13.20^{\prime \prime} \mathrm{S} \\
65^{\circ} 27^{\prime} 10.20^{\prime \prime} \mathrm{W}\end{array}$ & 860 & 80 & 10 & 100 & 0 \\
\hline San Javier River 1 & SJ1 & $\begin{array}{l}26^{\circ} 42^{\prime} 28.78^{\prime \prime} \mathrm{S} \\
65^{\circ} 22^{\prime} 44.45^{\prime \prime} \mathrm{W}\end{array}$ & 1221 & 60 & 18 & 81 & 19 \\
\hline San Javier River 2 & SJ2 & $\begin{array}{l}26^{\circ} 44^{\prime} 57.48^{\prime \prime} \mathrm{S} \\
65^{\circ} 23^{\prime} 13.92^{\prime \prime} \mathrm{W}\end{array}$ & 995 & 40 & 14 & 65 & 35 \\
\hline Los Noques River 1 & LN1 & $\begin{array}{l}26^{\circ} 47^{\prime} 10.00^{\prime \prime} \mathrm{S} \\
65^{\circ} 27^{\prime} 57.59^{\prime \prime} \mathrm{W}\end{array}$ & 914 & 50 & 15 & 80 & 20 \\
\hline Muerto River 1 & Mul & $\begin{array}{l}26^{\circ} 48^{\prime} 42.00^{\prime \prime} \mathrm{S} \\
65^{\circ} 19^{\prime} 34.00^{\prime \prime} \mathrm{W}\end{array}$ & 496 & 5 & 16 & 44 & 54 \\
\hline San Pablo Stream 1 & SP1 & $\begin{array}{l}26^{\circ} 51^{\prime} 50.00^{\prime \prime} \mathrm{S} \\
65^{\circ} 20^{\prime} 37.00^{\prime \prime} \mathrm{W}\end{array}$ & 581 & 20 & 15 & 53 & 47 \\
\hline Lules River 4 & $\mathrm{Lu} 4$ & $\begin{array}{l}26^{\circ} 54^{\prime} 20.08^{\prime \prime} \mathrm{S} \\
65^{\circ} 21^{\prime} 38.39^{\prime \prime} \mathrm{W}\end{array}$ & 453 & 55 & 23 & 79 & 21 \\
\hline Colorado River 1 & Col & $\begin{array}{c}26^{\circ} 59^{\prime} 3.98^{\prime \prime} \mathrm{S} ; \\
65^{\circ} 22^{\prime} 10.95^{\prime \prime} \mathrm{W}\end{array}$ & 392 & 5 & 10 & 73 & 27 \\
\hline
\end{tabular}

To assess whether the conservation status of the riparian forests influences the water quality of the adjacent rivers, we derived Pearson correlations between QBRy and TSS. In this case, the analysis considered TSS values for both wet and dry seasons, so it was possible to evaluate the period of the year in which riparian vegetation provides better buffer protection to the rivers.

The data used for all the correlations were transformed to a logarithmic scale to standardize. Given that the tables for correlations presented "zero entries," we added "1" to each value while performing transformation logarithms. Analyses were performed using the statistical software R [45].

\section{Results}

We identified 90 plant species, $77 \%$ of which were native (Table 2). More than half of the species were trees (60\%); adding the bushes, the percentage rises to $83 \%$, representing together the two life forms that structure the plant communities in these riparian forests. The species present in most of the sites were Morus alba (11 sites), Acacia aroma (10 sites),
Baccharis salicifolia (9 sites), and Phenax laevigatus (8 sites). The range of values of the QBRy index varied between 5 and 80 (Table 1). The lower values of the index indicated a bad status and extreme degradation $(<25)$. A noteworthy feature of these riparian forests is that they are located in areas of plains and highly disturbed by the change in land use (urbanized areas and crops).

Intermediate values of QBRy corresponded to recreational or touristic riverbanks (e.g., Raco River and Los Noques River). The highest values (75-90) indicating a good and slightly disturbed riparian forest belonged to two sites of Lules River located at remote areas (far away from human impact but cattle feces were detected in these sites, which is also a disturbance to the habitat).

The QBRy index correlated significantly with altitude $(r=$ 0.65 , $\mathrm{df}=14$, and $p=0.006)$ and the percentage of exotic plants $(r=-0.62$, $\mathrm{df}=14$, and $p=0.01)$. The correlations between QBRy and species richness $(r=0.14$, df $=14$, and $p=0.59)$, TSS in the wet season $(r=-0.09$, $\mathrm{df}=14$, and $p=0.71)$, and TSS in the dry season $(r=-0.34$, $\mathrm{df}=12$, and $p=0.23)$ were nonsignificant. The concentration of TSS was 
TABLE 2: List of identified taxa, indicating family, habit, and origin (native $=\mathrm{N}$ or exotic $=\mathrm{E}$ ).

\begin{tabular}{|c|c|c|c|}
\hline Taxa & Family & Habit & Origin \\
\hline Acacia aroma Gillies ex Hook. \& Arn. & Fabaceae & Tree & $\mathrm{N}$ \\
\hline Acacia praecox Griseb. & Fabaceae & Tree & $\mathrm{N}$ \\
\hline Acacia visco Lorentz ex Griseb. & Fabaceae & Tree & $\mathrm{N}$ \\
\hline Aechmea distichantha Lem. & Bromeliaceae & Epiphyte & $\mathrm{N}$ \\
\hline Allophylus edulis (A. St.-Hil., A. Juss. \& Cambess.) Hieron. ex Niederl. & Sapindaceae & Tree & $\mathrm{N}$ \\
\hline Anadenanthera colubrina (Vell.) Brenan & Fabaceae & Tree & $\mathrm{N}$ \\
\hline Arundo donax L. & Poaceae & Rattan & $\mathrm{E}$ \\
\hline Aspidosperma quebracho-blanco Schltdl. & Apocynaceae & Tree & $\mathrm{N}$ \\
\hline Baccharis salicifolia (Ruiz \& Pav.) Pers. & Asteraceae & Shrub & $\mathrm{N}$ \\
\hline Baccharis tucumanensis Hook. \& Arn. & Asteraceae & Shrub & $\mathrm{N}$ \\
\hline Blepharocalyx salicifolius (Kunth) O. Berg & Myrtaceae & Tree & $\mathrm{N}$ \\
\hline Boehmeria caudata Sw. & Urticaceae & Shrub & $\mathrm{N}$ \\
\hline Broussonetia papyrifera (L.) Vent. & Moraceae & Tree & $\mathrm{E}$ \\
\hline Cedrela angustifolia DC. & Meliaceae & Tree & $\mathrm{N}$ \\
\hline Ceiba chodatii (Hassl.) Ravenna & Bombacaceae & Tree & $\mathrm{N}$ \\
\hline Celtis iguanaea (Jacq.) Sarg. & Celtidaceae & Tree & $\mathrm{N}$ \\
\hline Cercidium praecox (Ruiz \& Pav. ex Hook.) Harms & Fabaceae & Tree & $\mathrm{N}$ \\
\hline Cestrum strigillatum Ruiz \& Pav. & Solanaceae & Shrub & $\mathrm{N}$ \\
\hline Citrus limon (L.) Osbeck & Rutaceae & Tree & $\mathrm{E}$ \\
\hline Citrus sinensis (L.) Osbeck & Rutaceae & Tree & $\mathrm{E}$ \\
\hline Clematis montevidensis Spreng. & Ranunculaceae & Climber & $\mathrm{N}$ \\
\hline Condalia buxifolia Reissek & Rhamnaceae & Tree & $\mathrm{N}$ \\
\hline Cupania vernalis Cambess. & Sapindaceae & Tree & $\mathrm{N}$ \\
\hline Dolichandra unguis-cati (L.) L.G. Lohmann & Bignoniaceae & Climber & $\mathrm{N}$ \\
\hline Enterolobium contortisiliquum (Vell.) Morong & Fabaceae & Tree & $\mathrm{N}$ \\
\hline Eriobotrya japonica (Thunb.) lindl. & Rosaceae & Tree & $\mathrm{E}$ \\
\hline Eucalyptus sp. & Myrtaceae & Tree & $\mathrm{E}$ \\
\hline Eugenia uniflora L. & Myrtaceae & Tree & $\mathrm{N}$ \\
\hline Geoffroea decorticans (Gillies ex Hook. \& Arn.) Burkart & Fabaceae & Tree & $\mathrm{N}$ \\
\hline Gleditsia triacanthos $\mathrm{L}$. & Fabaceae & Tree & $\mathrm{E}$ \\
\hline Guadua angustifolia Kunth & Poaceae & Rattan & $\mathrm{E}$ \\
\hline Handroanthus impetiginosus (Mart. ex DC.) Mattos & Bignoniaceae & Tree & $\mathrm{N}$ \\
\hline Ipomoea alba L. & Convolvulaceae & Climber & $\mathrm{N}$ \\
\hline Jacaranda mimosifolia D. Don & Bignoniaceae & Tree & $\mathrm{N}$ \\
\hline Juglans australis Griseb. & Juglandaceae & Tree & $\mathrm{N}$ \\
\hline Juglans regia $\mathrm{L}$. & Juglandaceae & Tree & $\mathrm{E}$ \\
\hline Lantana camara L. & Verbenaceae & Shrub & $\mathrm{N}$ \\
\hline Ligaria cuneifolia (Ruiz \& Pav.) Tiegh. & Loranthaceae & Epiphyte & $\mathrm{N}$ \\
\hline Ligustrum lucidum W.T. Aiton & Oleaceae & Tree & $\mathrm{E}$ \\
\hline Lycium sp. & Solanaceae & Shrub & $\mathrm{N}$ \\
\hline Manihot sp. & Euphorbiaceae & Shrub & $\mathrm{E}$ \\
\hline Maytenus vitis-idaea Griseb. & Celastraceae & Tree & $\mathrm{N}$ \\
\hline Mikania cordifolia (L. f.) Willd. & Asteraceae & Climber & $\mathrm{N}$ \\
\hline Mikania periplocifolia Hook. \& Arn. & Asteraceae & Climber & $\mathrm{N}$ \\
\hline Morrenia odorata (Hook. \& Arn.) Lindl. & Apocynaceae & Climber & $\mathrm{N}$ \\
\hline Morus alba L. & Moraceae & Tree & $\mathrm{E}$ \\
\hline Myrcianthes mato (Griseb.) McVaugh & Myrtaceae & Tree & $\mathrm{N}$ \\
\hline Myrsine coriacea (Sw.) R. Br. & Myrsinaceae & Tree & $\mathrm{N}$ \\
\hline Myrsine laetevirens (Mez) Arechav. & Myrsinaceae & Tree & $\mathrm{N}$ \\
\hline
\end{tabular}


TABLE 2: Continued.

\begin{tabular}{|c|c|c|c|}
\hline Taxa & Family & Habit & Origin \\
\hline Nicotiana glauca Graham & Solanaceae & Shrub & $\mathrm{N}$ \\
\hline Ocotea porphyria (Griseb.) van der Werff & Lauraceae & Tree & $\mathrm{N}$ \\
\hline Opuntia ficus-indica (L.) Mill. & Cactaceae & Shrub & $\mathrm{E}$ \\
\hline Opuntia quimilo K. Schum. & Cactaceae & Tree & $\mathrm{N}$ \\
\hline Opuntia sulphurea Gillies ex Salm-Dyck & Cactaceae & Shrub & $\mathrm{N}$ \\
\hline Phenax laevigatus Wedd. & Urticaceae & Shrub & $\mathrm{N}$ \\
\hline Phytolacca bogotensis Kunth & Phytolaccaceae & Shrub & $\mathrm{N}$ \\
\hline Pinus sp. & Pinaceae & Tree & $\mathrm{E}$ \\
\hline Piper hieronymi C. DC & Piperaceae & Shrub & $\mathrm{N}$ \\
\hline Platanus occidentalis L. & Platanaceae & Tree & $\mathrm{E}$ \\
\hline Populus deltoides W. Bartram ex Marshall & Salicaceae & Tree & $\mathrm{E}$ \\
\hline Prosopis sp. & Fabaceae & Tree & $\mathrm{N}$ \\
\hline Proustia cuneifolia D. Don & Asteraceae & Shrub & $\mathrm{N}$ \\
\hline Prunus persica (L.) Batsch & Rosaceae & Tree & $\mathrm{E}$ \\
\hline Psidium guajava $\mathrm{L}$. & Myrtaceae & Tree & $\mathrm{E}$ \\
\hline Quechualia fulta (Griseb.) H. Rob. & Asteraceae & Climber & $\mathrm{N}$ \\
\hline Ricinus communis $\mathrm{L}$. & Euphorbiaceae & Shrub & $\mathrm{E}$ \\
\hline Rubus imperialis Cham. \& Schltdl. & Rosaceae & Shrub & $\mathrm{N}$ \\
\hline Ruta chalepensis L. & Rutaceae & Shrub & $\mathrm{E}$ \\
\hline Salix humboldtiana Willd. & Salicaceae & Tree & $\mathrm{N}$ \\
\hline Schinopsis lorentzii (Griseb.) Engl. & Anacardiaceae & Tree & $\mathrm{N}$ \\
\hline Schinus bumelioides I.M. Johnst. & Anacardiaceae & Tree & $\mathrm{N}$ \\
\hline Schinus fasciculatus (Griseb.) I.M. Johnst. & Anacardiaceae & Tree & $\mathrm{N}$ \\
\hline Scutia buxifolia Reissek & Rhamnaceae & Tree & $\mathrm{N}$ \\
\hline Serjania meridionalis Cambess. & Sapindaceae & Climber & $\mathrm{N}$ \\
\hline Solanum paniculatum L. & Solanaceae & Shrub & $\mathrm{N}$ \\
\hline Solanum riparium Pers. & Solanaceae & Tree & $\mathrm{N}$ \\
\hline Suaeda divaricata Moq. & Chenopodiaceae & Shrub & $\mathrm{N}$ \\
\hline Syagrus romanzoffiana (Cham.) Glassman & Arecaceae & Palm & $\mathrm{E}$ \\
\hline Tecoma stans (L.) Juss. ex Kunth & Bignoniaceae & Tree & $\mathrm{N}$ \\
\hline Tessaria absinthioides (Hook. \& Arn.) DC. & Asteraceae & Shrub & $\mathrm{N}$ \\
\hline Tillandsia sp. & Bromeliaceae & Epiphyte & $\mathrm{N}$ \\
\hline Tipuana tipu (Benth.) Kuntze & Fabaceae & Tree & $\mathrm{N}$ \\
\hline Trema micrantha (L.) Blume & Celtidaceae & Tree & $\mathrm{N}$ \\
\hline Tripodanthus acutifolius (Ruiz \& Pav.) Tiegh. & Loranthaceae & Epiphyte & $\mathrm{N}$ \\
\hline Urera baccifera (L.) Gaudich. & Urticaceae & Tree & $\mathrm{N}$ \\
\hline Urera caracasana (Jacq.) Gaudich. ex Griseb. & Urticaceae & Tree & $\mathrm{N}$ \\
\hline Vassobia breviflora (Sendtn.) Hunz. & Solanaceae & Tree & $\mathrm{N}$ \\
\hline Verbesina suncho (Griseb.) S.F. Blake & Asteraceae & Shrub & $\mathrm{N}$ \\
\hline Zanthoxylum coco Gillies ex Hook. f. \& Arn. & Rutaceae & Tree & $\mathrm{N}$ \\
\hline Ziziphus mistol Griseb. & Rhamnaceae & Tree & $\mathrm{N}$ \\
\hline
\end{tabular}

considerably lower at dry station for all the sites, and some of them did not have water at all (Table 3).

The NMDS (Figure 2) did not separate the sites based on identity of the forests (Chaco and Yungas sites were dispersed and mixed in the graph). The sites were ordered mainly based on the dominance of exotic species, locating forests that have less exotic species in the negative side of axis 1 and sites with more invasive species in the positive side of axis 1 . The percentage of native and exotic species was related to the altitude of the sites (see the size of the symbols).

\section{Discussion}

The surveyed plants species in the province of Tucumán were mostly native and included different life forms (i.e., trees, shrubs, palms, rattans, lianas, and epiphytes). In order to achieve a more complete assessment of their conservation status, we strongly believe that a quality analysis of riparian forests should include all the varieties of life forms. The number of species presented here is greater than that observed in other studies in the same province $[16,17,26]$, probably 
TABLE 3: Average concentration of TSS at humid and dry seasons for each sampled site. The standard deviation for humid season is 0.05 and for dry season it is not informed because of the existence of many sites without water (ww) and so there is no data to inform.

\begin{tabular}{lcc}
\hline $\begin{array}{l}\text { Site } \\
\text { codification }\end{array}$ & $\begin{array}{c}\text { Average } \\
\text { concentration of TSS } \\
(\mathrm{mg} / \mathrm{L})\end{array}$ & $\begin{array}{c}\text { in wet season } \\
\text { concentration of TSS } \\
(\mathrm{mg} / \mathrm{L})\end{array}$ \\
\hline Sa1 dry season
\end{tabular}

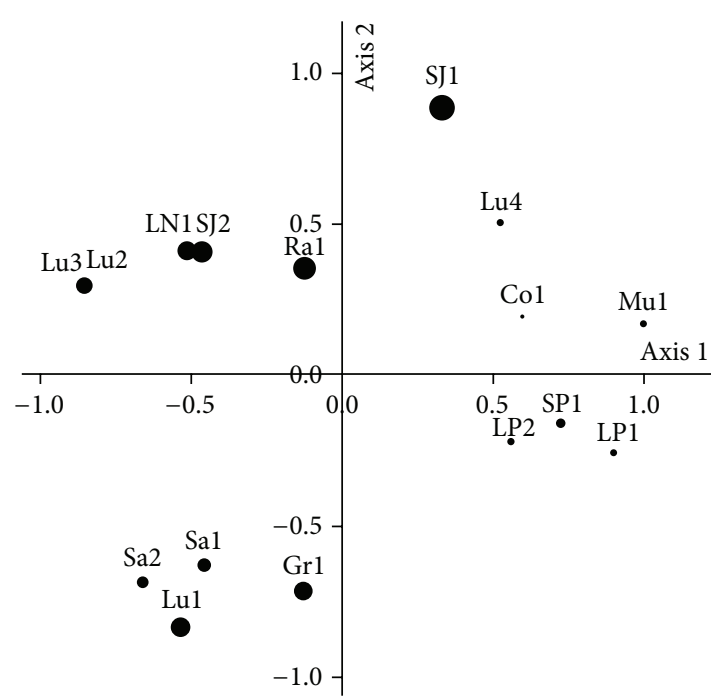

FIGURE 2: NMDS showing the sites in relation to species composition ordering. Increasing size symbols indicate increasing altitude.

because our study area was wider (i.e., species-area effect [46, 47]), comprising both Yungas and Chaco forests, with different species composition. Similarly to most riparian forests in the world, the structure was dominated by woody plants, such as trees and bushes [19]. Exotic species were also present and they were dominant in several sites. The most common exotic species were Ligustrum lucidum, Morus alba, Arundo donax, and Gleditsia triacanthos. The main problem we find considering this point is that they can represent a big barrier for the establishment of native vegetation [48]. Previous studies in the same study area showed that these exotic plants have the ability to invade and displace native species, thus reducing their diversity $[49,50]$. For example, $G$. triacanthos, one of the most important invasive plant species of Tucumán, caused major physiognomic and structural changes in some areas of Lules River Basin and Sierra de San Javier [16]. These "new forests," dominated by invasive species, acquired xeric characteristics which differ widely from the original riparian forests characteristic from Yungas ecoregion [16]; thus, it is likely that these changes derive in ecological consequences in the area [51]. In other ecoregions of Argentina (e.g., estepa patagonica, Monte, Espinal), invasive species are also changing the structure of riparian communities, with consequences for ecosystem functioning [52]. For example, in Pampean streams of the province of Buenos Aires, G. triacanthos modified the structure from grasslands to forests, causing changes in the richness of invertebrates and the composition of aquatic species, probably due to reduced light conditions [53]. On the other hand, exotic leaves may have different physical and chemical characteristics (leaf toughness, leaf area, content of cellulose, hemicelluloses, lignin, C, and $\mathrm{N})$ from native ones, which might negatively influence the activity of detritivores invertebrates [54].

The variation of QBRy values was strongly associated with the altitude of the sampled area, since riparian forests located at lowlands were highly disturbed. Although there are some exceptions [55], it is well known that degradation is higher at lower altitudes, where anthropogenic impact is usually more intense and land is more accessible for different uses [26]. In the study area, riparian forests of lowland rivers are close to urban zones and extensive agriculture areas (e.g., fruit crops and sugarcane) and had a low degree of conservation. In these areas, the anthropogenic impact continues to increase and these forests are becoming narrow strips, for which urgent conservation measures are required in these areas, especially in Yungas piedmont [56]. Other uses, such as recreational activities, did not significantly affect the conservation status of riparian forests, since they usually take place at specific sectors (i.e., not over all river margins) and exhibited intermediate values of QBRy. However, it should be taken into account that recreational activities might also imply alterations in the form of degradation or removal of vegetation cover [57].

The greatest anthropic impact at lower altitude sites and the differences in species composition due to the altitudinal gradient [15] may explain changes in the richness and composition of aquatic and marsh vegetation at the surveyed watercourses. At mountain watercourses, mainly in zones of quiet waters, the vegetation was that typical of flooded and waterlogged habitats [58], with species like Bacopa monnieri (Plantaginaceae), Myriophyllum aquaticum (Haloragaceae), Hydrocotyle bonariensis (Apiaceae), and Pluchea sagittalis (Asteraceae). At areas of lower altitude, we found formations of Heimia salicifolia (Lythraceae) and Ludwigia peploides (Onagraceae) in sediment banks and a less diversity of aquatic and marsh plant communities. This could be due to the fact that these communities are very sensitive to the destabilizing effect of external disturbances [59]. Moreover, runoff during 
wet season significantly influences the stability and resilience of plant communities at lower altitude areas.

There was no relationship between QBRy and water TSS content in wet and dry seasons. Perhaps other factors are more appropriate than riparian forest quality as determinants of TSS in water. For example, an earlier study made in this area showed that in 2012 (>1.200 $\mathrm{mm}$ of precipitations during humid period) the higher concentrations of TSS were directly related to the discharge of rivers and streams [60].

\section{Conclusions}

Riparian forests surveyed in Tucumán province exhibit a variable conservation status, but most of them present some degree of degradation, mainly due to human impact. Despite the wide variability observed with the QBRy index, some patterns derived from altitude can be identified. The altitudinal gradient determines that riparian forests located in lower areas present a low conservation status, since they coexist with human activities in adjacent areas, with great impact on their conservation. In turn, the altitudinal gradient also determines changes in plant species composition among forests, with a higher percentage of exotic species at lower altitudes. The absence of a relationship between riparian forests quality and TSS in water in the study area suggests that flow is a more relevant factor influencing TSS concentrations. Like other riparian forests of Argentina, degradation is increasing dramatically in the study area. Therefore, habitat conservation and management, particularly at lower altitudes, appear as a priority for future studies.

\section{Competing Interests}

The authors Romina Daiana Fernández, Sergio Javier Ceballos, Ana Lucía González Achem, Margarita del Valle Hidalgo, and Hugo Rafael Fernández declare that there are no competing interests regarding the publication of this paper.

\section{Acknowledgments}

The authors thank CONICET for supporting their work, as well as Project of CIUNT "Desarrollo de Indices de Calidad de Aguas (ICA) para la Provincia de Tucumán," Code 26/G422. They are grateful to Rafael Escobar, Gabriela Araujo, Guillermo Hankel, Luciana Ruiz, Guillermo Terán, Ana Martínez, Alejandra Cocimano, Ariana Sanchez, Álvaro Galbán, César Moreno, and Laura Rolandi for their selfless help with field and laboratory work. They are especially grateful to Sofia Nanni for the English revision.

\section{References}

[1] G. P. Malanson, Riparian Landscapes, Cambridge University Press, Cambridge, UK, 1993.

[2] S. Wenger, A Review of the Scientific Literature on Riparian Buffer Width, Extent and Vegetation, Office of Public Service and Outreach Institute of Ecology University of Georgia, 1999.
[3] R. L. Vannote, G. W. Minshall, K. W. Cummins, J. R. Sedell, and C. E. Cushing, "The river continuum concept," Canadian Journal of Fisheries and Aquatic Sciences, vol. 37, no. 1, pp. 130137, 1980.

[4] J. D. Allan, Stream Ecology: Structure and Function of Running Waters, Chapman \& Hall, London, UK, 1995.

[5] M. A. S. Graça, "The role of invertebrates on leaf litter decomposition in streams-a review," International Review of Hydrobiology, vol. 86, no. 4-5, pp. 383-393, 2001.

[6] J. E. Clapcott, R. G. Young, J. S. Harding, C. D. Matthaei, J. M. Quinn, and R. G. Death, Sediment Assessment Methods: Protocols and Guidelines for Assessing the Effects of Deposited Fine Sediment on in-Stream Values, Cawthron Institute, Nelson, New Zealand, 2011.

[7] N. L. Poff, B. D. Richter, A. H. Arthington et al., "The ecological limits of hydrologic alteration (ELOHA): a new framework for developing regional environmental flow standards," Freshwater Biology, vol. 55, no. 1, pp. 147-170, 2010.

[8] G. S. Bilotta and R. E. Brazier, "Understanding the influence of suspended solids on water quality and aquatic biota," Water Research, vol. 42, no. 12, pp. 2849-2861, 2008.

[9] M. Strand and R. W. Merritt, "Impacts of livestock grazing activities on stream insect communities and the riverine environment," American Entomologist, vol. 45, no. 1, pp. 13-29, 1999.

[10] M. J. Kennard, B. J. Pusey, A. H. Arthington, B. D. Harch, and S. J. Mackay, "Development and application of a predictive model of freshwater fish assemblage composition to evaluate river health in eastern Australia," Hydrobiología, vol. 572, no. 1, pp. 33-57, 2006.

[11] L. Pizzolón, M. L. Miserendino, and L. Arias, Inventario de Perturbaciones Antrópicas Sobre los Ambientes Acuáticos de Chubut, Resúmenes de las Jornadas Patagónicas de Medio Ambiente, Esquel, Argentina, 1996.

[12] M. L. Miserendino, "Effects of landscape and desertification on the macroinvertebrate assemblages of rivers in Andean Patagonia," Archiv für Hydrobiologie, vol. 159, no. 2, pp. 185-209, 2004.

[13] P. F. Temporetti, "Efecto a largo plazo de los incendios forestales en la calidad del agua de dos arroyos en la subregión AndinoPatagónica, Argentina," Ecología Austral, vol. 16, no. 2, pp. 157166, 2006.

[14] M. L. Miserendino, C. Brand, and C. Y. Di Prinzio, "Assessing urban impacts on water quality, benthic communities and fish in streams of the Andes mountains, Patagonia (Argentina)," Water, Air, and Soil Pollution, vol. 194, no. 1-4, pp. 91-110, 2008.

[15] M. G. Sirombra, "Q.B.R.y una propuesta ecológica para evaluar la calidad del bosque ribereño en ríos de yungas del Noroeste Argentino," Serie Monográfica y Didáctica, vol. 48, p. 248, 2009.

[16] M. G. Sirombra and L. M. Mesa, "Composición florística y distribución de los bosques ribereños subtropicales andinos del Río Lules, Tucumán, Argentina," Revista de Biología Tropical, vol. 58, no. 1, pp. 499-510, 2010.

[17] P. A. Quiroga, H. R. Fernández, M. G. Sirombra, and E. Domínguez, "Riparian forests and cattle management problems in Andean subtropical streams: in the search of quality water sustainability," Lilloa, vol. 48, no. 1, pp. 36-52, 2011.

[18] W. G. Hood and R. J. Naiman, "Vulnerability of riparian zones to invasion by exotic vascular plants," Plant Ecology, vol. 148, no. 1, pp. 105-114, 2000.

[19] D. M. Richardson, P. M. Holmes, K. J. Esler et al., "Riparian vegetation: degradation, alien plant invasions, and restoration 
prospects," Diversity and Distributions, vol. 13, no. 1, pp. 126-139, 2007.

[20] I. M. Parker and S. H. Reichard, "Critical issues in invasion biology for conservation science," in Conservation Biology for the Coming Decade, P. L. Fiedlerand and P. M. Kareiva, Eds., pp. 283-305, Chapman and Hall, 1997.

[21] M. I. Posada-Posada and M. D. P. Arroyave Maya, "Análisis de la calidad del retiro ribereño para el diseño de estrategias de restauración ecológica en el río La Miel, Caldas, Colombia," Revista EIA, vol. 12, pp. 117-128, 2015.

[22] A. Munné, C. Solá, and N. Prat, "QBR: Un índice rápido para la evaluación de la calidad de los ecosistemas de ribera," Tecnología del Agua, vol. 175, pp. 20-37, 1998.

[23] M. L. Suárez, M. R. Vidal-Abarca, M. M. Sánchez Montoya et al., "Las riberas de los ríos mediterráneos y su calidad: el uso del índice QBR," Limnetica, vol. 21, no. 3-4, pp. 135-148, 2004.

[24] A. Kutschker, C. Brand, and M. L. Miserendino, "Evaluación de la calidad de los bosques de ribera en ríos del NO del Chubut sometidos a distintos usos de la tierra," Ecología Austral, vol. 19, pp. 19-34, 2009.

[25] A. Palma, R. Figueroa, and V. H. Ruiz, "Evaluación de ribera y hábitat fluvial a través de los índices QBR e IHF," Gayana, vol. 73, no. 1, pp. 57-63, 2009.

[26] M. G. Sirombra and L. M. Mesa, "A method for assessing the ecological quality of riparian forests in subtropical Andean streams: QBRy index," Ecological Indicators, vol. 20, pp. 324-331, 2012.

[27] M. G. Sirombra, Diagnóstico y propuestas de gestión ambiental sobre la base del estudio de calidad de ecosistemas rivereños en un sector del pedemonte oriental de la Sierra de San Javier, Provincia de Tucumán, Argentina [Ph.D. thesis], Universidad Nacional de Tucumán, Facultad de Ciencias Naturales e Instituto Miguel Lillo, 2012.

[28] H. Hunzinger, "La precipitación horizontal: Su importancia para el bosque y a nivel de cuencas en la Sierra San Javier, Tucumán, Argentina," in Investigación, Conservación y Desarrollo en Selvas Subtropicales de Montaña, A. Brown and H. R. Grau, Eds., pp. 53-58, LIEY, Tucumán, Argentina, 1995.

[29] A. L. Cabrera, "Fitogeografía de la República Argentina," Boletín de la Sociedad Argentina de Botánica, vol. 14, pp. 1-42, 1971.

[30] A. L. Cabrera and A. Willink, "Regiones biogeográficas en América Latina," in Biogeografía de América Latina, E. Chesneau, Ed., Serie de Biología, Monografía no. 13, chapter 8, pp. 29-107, Secretaría de la Organización de los Estados Americanos, Programa de Desarrollo Científico y Tecnológico, 1980.

[31] A. D. Brown, H. R. Grau, L. R. Malizia, and A. Grau, "Argentina," in Bosques Nublados del Neotrópico, M. Kappelle and A. D. Brown, Eds., pp. 623-658, INBIO, Santo Domingo de Heredia, Costa Rica, 2001.

[32] A. L. Cabrera, Regiones Fitogeográficas Argentinas, vol. 1, Editorial Acme, 1976.

[33] A. Malizia and H. R. Grau, "Liana-host tree associations in a subtropical montane forest of north-western Argentina," Journal of Tropical Ecology, vol. 22, no. 3, pp. 331-339, 2006.

[34] A. Grau and A. D. Brown, "Development threats to biodiversity and opportunities for conservation in the mountain ranges of the Upper Bermejo River Basin, NW Argentina and SW Bolivia," Ambio, vol. 29, no. 7, pp. 445-450, 2000.

[35] A. Malizia, P. I. Campanello, M. Villagra, and S. Ceballos, "Geographical, taxonomical and ecological aspects of lianas in subtropical forests of Argentina," in Biodiversity of Lianas,
Sustainable Development and Biodiversity, N. Parthasarathy, Ed., pp. 17-42, 2015.

[36] S. A. Torrella and J. Adámoli, "Situación ambiental de la ecorregión del Chaco Seco," in La Situación Ambiental Argentina, A. Brown, U. Martinez Ortiz, M. Acerbi, and J. Corcuera, Eds., pp. 75-82, Fundación Vida Silvestre, Buenos Aires, Argentina, 2006.

[37] F. O. Zuloaga, O. Morrone, and M. J. Belgrano, "Catalogue of the vascular plants of the southern cone (Argentina, Southern Brazil, Chile, Paraguay and Uruguay)," in Dicotyledoneae: Acanthaceae-Fabaceae (Abarema-Schizolobium), vol. 2, p. 985, Missouri Botanical Garden Press, 2008.

[38] The Nature Conservancy (TNC), Fundación Vida Silvestre Argentina (FVSA), Fundación para el Desarrollo Sustentable del Chaco (DeSdel Chaco) and Wildife Conservation Society Bolivia (WCS), Evaluación Ecorregional del Gran Chaco Americano/Gran Chaco Americano Ecorregional Assessment, Fundación Vida Silvestre, Buenos Aires, Argentina, 2005.

[39] TROPICOS, Missouri Botanical Garden, 2015, http://www.tropicos.org.

[40] Instituto Argentino de Normalización y Certificación IRAM 29012-2: Técnicas de muestreo. IRAM 29012-3: Calidad ambiental. Calidad del agua. Muestreo. Parte 3: Guía para la preservación y manipulación de las muestras. IRAM 29012-6: Calidad ambiental. Calidad del agua. Muestreo: Parte 6: Directivas para el muestreo en ríos y cursos de agua. IRAM 29012-14: Calidad ambiental. Calidad del agua. Muestreo: Parte 14: Directivas sobre aseguramiento de la calidad del muestreo y manipulación de agua, 2012, http://www.iram.org.ar/.

[41] J. Rodier, Análisis de las Aguas. Aguas Naturales. Aguas Residuales. Agua de Mar. Química, Fisicoquímica, Bacteriología, Biología, Ediciones Omega, Barcelona, Spain, 1989.

[42] APHA, Standard Methods, American Public Health Association, Washington, DC, USA, 17th edition, 1998.

[43] J. Carrasco, Comparación de un modelo paramétrico de producción de sedimentos con valores experimentales, en cuencas de la provincia de Tucumán Argentina [Ph.D. thesis], Thesis of Licenciature degree in Ciencias Biológicas de la Facultad de Ciencias Naturales e Instituto Miguel Lillo, Universidad Nacional de Tucumán, Argentina, 2013.

[44] B. McCunne and J. B. Grace, Analysis of Ecological Communities, MjM Software, Gleneden Beach, Ore, USA, 2002.

[45] R Core Team, R: A Language and Environment for Statistical Computing, R Foundation for Statistical Computing, Vienna, Austria, 2015, http://www.R-project.org/.

[46] R. H. MacArthus and E. O. Wilson, The Theory of Island Biogeography, Princeton University Press, 1967.

[47] M. L. Rosenzweig, Species Diversity in Space and Time, Cambridge University Press, Cambridge, UK, 1995.

[48] F. D. Shields, A. J. Bowie, and C. M. Cooper, "Control of streambank erosion due to bed degradation with vegetation and structure," Journal of the American Water Resources Association, vol. 31, no. 3, pp. 475-489, 1995.

[49] H. R. Grau and R. Aragón, “Árboles invasores de la Sierra de San Javier," in Árboles Exóticos de las Yungas Argentinas, LIEYUNT, H. R. Grau and R. Aragón, Eds., pp. 5-20, 2000.

[50] R. Aragón and M. Groom, "Invasion by Ligustrum lucidum (Oleaceae) in NW Argentina: early stage characteristics in different habitat types," Revista de Biologia Tropical, vol. 51, no. 1, pp. 59-70, 2003. 
[51] P. A. Quiroga and J. P. Juliá, "Estudio de una cuenca de río subtropical de montaña: pautas para su gestión ecosistémica," in La Cuenca del Río Lules: Una Aproximación Multidisciplinaria a su Complejidad, H. R. Fernandez and H. Barber, Eds., pp. 159174, Editorial Edunt, 2011.

[52] P. Gantes, A. V. Marano, and L. Rigacci, "Changes in the decomposition process associated with the invasion of Gleditsia triacanthos (honey locust) in pampean streams (Buenos Aires, Argentina)," Journal of Freshwater Ecology, vol. 26, no. 4, pp. 481-494, 2011.

[53] A. Giorgi, C. Vilches, M. C. R. Castro et al., "Honey locust (Gleditsia triacanthos L. (Fabaceae)) invasion effect on temperature, light and metabolism of a pampean stream," Acta Biologica Colombiana, vol. 19, no. 1, pp. 99-105, 2014.

[54] I. W. Ashton, L. A. Hyatt, K. M. Howe, J. Gurevitch, and M. T. Lerdau, "Invasive species accelerate decomposition and litter nitrogen loss in a mixed deciduous forest," Ecological Applications, vol. 15, no. 4, pp. 1263-1272, 2005.

[55] E. Valero, J. Picos, and X. Álvarez, "Characterization of riparian forest quality of the Umia River for a proposed restoration," Ecological Engineering, vol. 67, pp. 216-222, 2014.

[56] D. E. Prado, "Selva pedemontana: contexto regional y lista florística de un ecosistema en peligro," in Investigación, Conservación y Desarrollo en Selvas Subtropicales de Montaña, A. D. Brown and H. R. Grau, Eds., pp. 19-52, L.I.E.Y., UNT, 1995.

[57] C. M. Gualdoni, C. A. Duarte, and E. A. Medeot, "Ecological status of two mountain streams of the south of Córdoba, Argentina," Ecologia Austral, vol. 21, no. 2, pp. 149-162, 2011.

[58] S. Rivas-Martínez, "Datos ecológicos sobre la vegetación acuática continental," Anales del Instituto Botánico Cavanilles, vol. 32, no. 1, pp. 199-205, 1975.

[59] C. Duarte, C. Montes, S. Agustí, P. Martino, M. Bernués, and J. Kallf, "Biomasa de macrófitos acuáticos en la marisma del parque nacional de Doñana (SW España): importancia y factores ambientales que controlan su distribución," Limnetica, vol. 6, pp. 1-12, 1990.

[60] M. C. Reynaga and D. A. Dos Santos, "Rasgos biológicos de macroinvertebrados de ríos subtropicales: patrones de variación a lo largo de gradientes ambientales espaciotemporales," Ecología Austral, vol. 22, no. 2, pp. 112-120, 2012. 

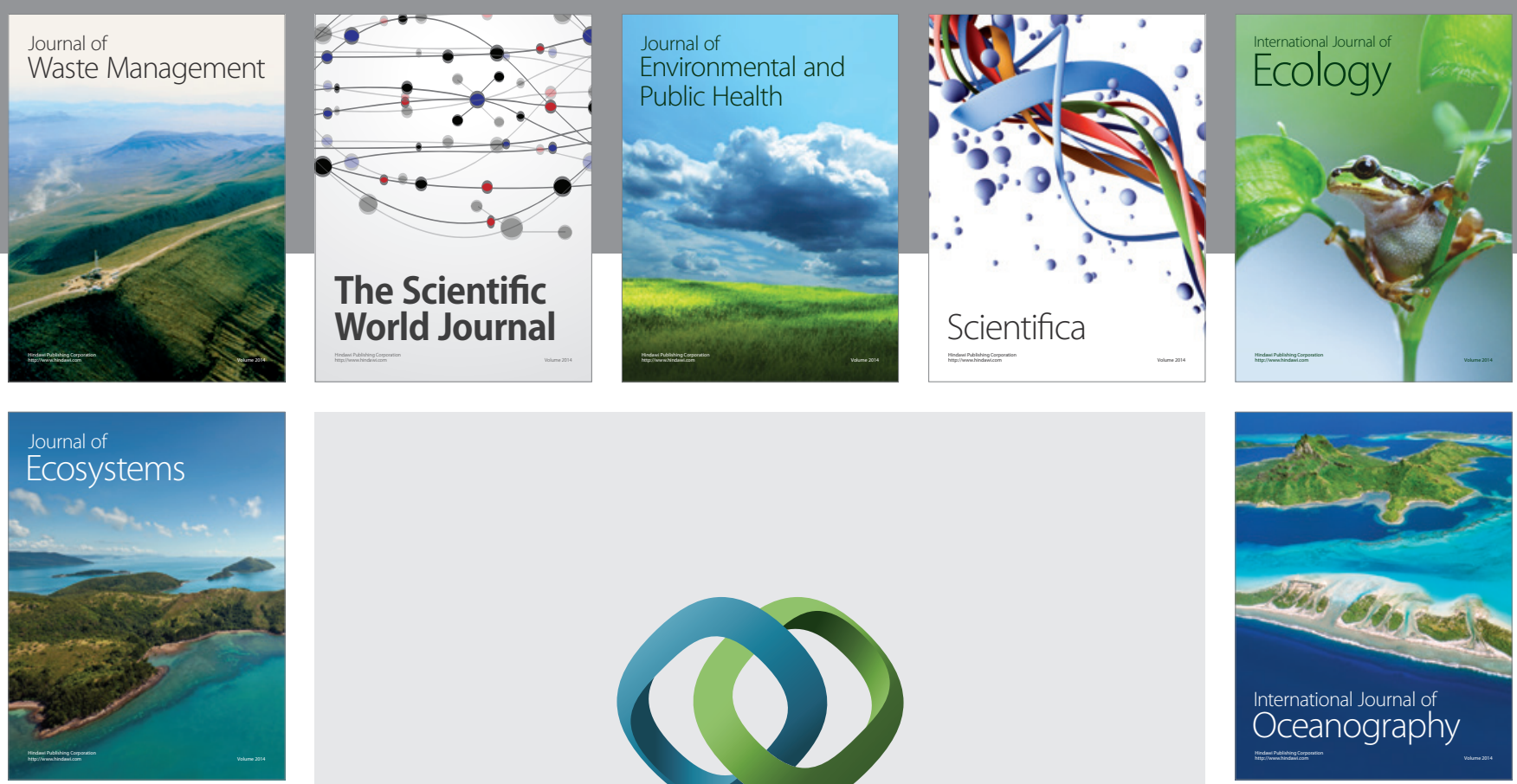

The Scientific World Journal
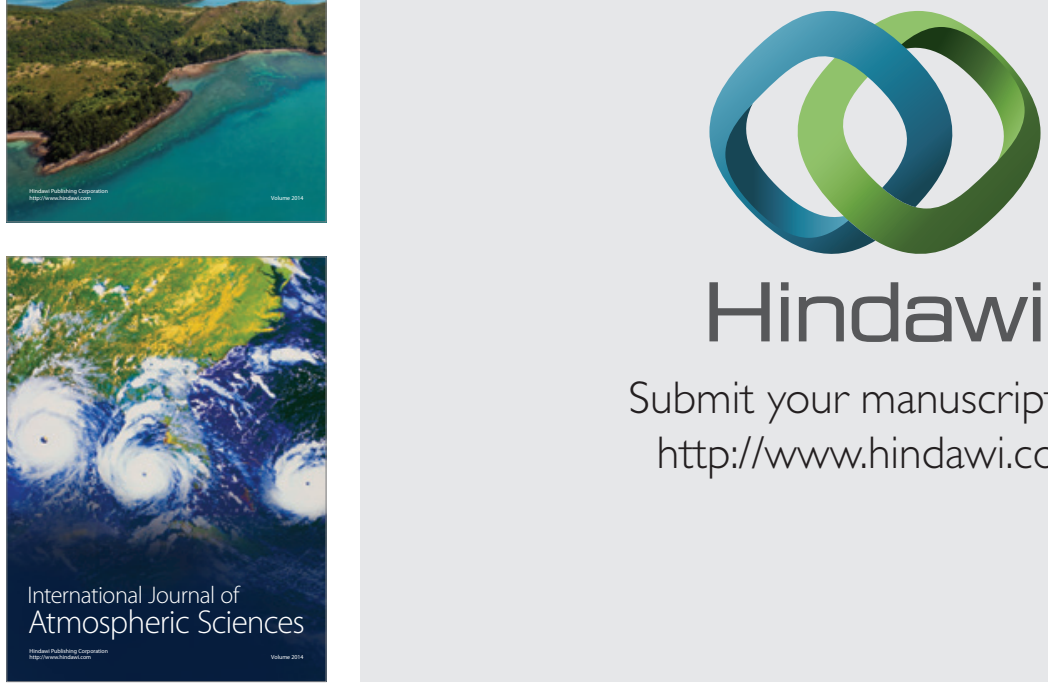

\section{Hindawi}

Submit your manuscripts at

http://www.hindawi.com
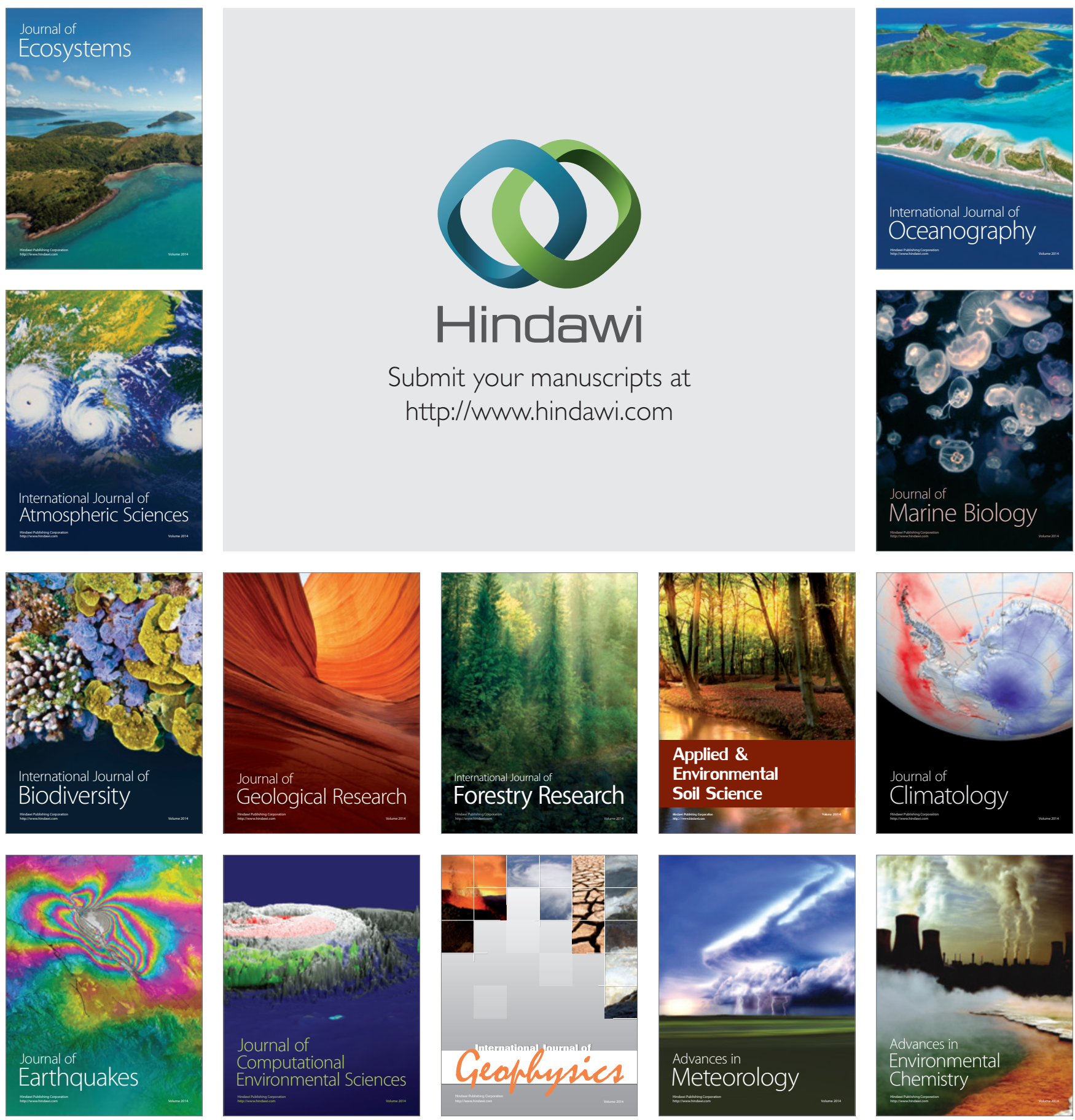